\title{
Immunocytokines for cancer treatment: past, present and future
}

Dario Neri $^{1}$ and Paul M. Sondel ${ }^{2}$

1) Department of Chemistry and Applied Biosciences, Swiss Federal Institute of Technology (ETH Zürich), Vladimir-Prelog-Weg 4, CH-8093 Zürich (Switzerland)

2) Departments of Pediatrics, Human Oncology and Genetics, and UW Carbone Cancer Center, University of Wisconsin, Madison WI (USA)

\section{Correspondence:}

Dario Neri

Tel: +41-44-6337401

e-mail: neri@pharma.ethz.ch

Paul M. Sondel

Tel: +1-608-263-9069

e-mail: pmsondel@humonc.wisc.edu 


\begin{abstract}
Immunocytokines are antibody-cytokine fusion proteins, with the potential to preferentially localize on tumor lesions and to activate anticancer immunity at the site of disease. Various tumor targets (e.g., cell membrane antigens and extracellular matrix components) and antibody formats (e.g., intact IgG and antibody fragments) have been considered for immunocytokine development and some products have advanced to clinical trials. In this review, we present relevant concepts and strategies for the design and use of anticancer immunocytokine products. In addition, we discuss emerging strategies for the pharmaceutical development and clinical application of this promising class of biopharmaceuticals.
\end{abstract}


From cytokines to immunocytokines

Cytokines are immunomodulatory proteins, which can activate or inhibit the activity of the immune system, depending on their properties and concentration, as well as the environment in which they operate. Some pro-inflammatory cytokines [e.g., interleukin-2 (IL2), tumor necrosis factor (TNF), interferon-alpha] have received marketing authorization for the treatment of certain types of malignancies. However, the systemic administration of these agents is often associated with dose-dependent side-effects (e.g., hypotension, flu-like symptoms, nausea, capillary leak), which prevent dose escalation to therapeutically active regimens. In principle, the fusion of cytokines to suitable antibody molecules, specific to tumor-associated antigens and capable of selective localization at the tumor site, should increase the therapeutic index of the bioactive payload.

\section{$\underline{\text { Immunocytokine formats }}$}

The first experimental implementations of the immunocytokine concept relied on the use of antibodies in intact IgG format. At a later stage, antibody fragments (e.g., scFv fragments and diabodies) were also considered for product development. While many cytokine payloads have been considered and have been tested at the preclinical level, most clinical activities are based on IL2, TNF and the heterodimeric interleukin-12 (IL12) cytokine. Both the antibody format and properties of the target antigen can have a profound impact on the performance and mechanism of action of immunocytokine products. Detailed reviews are available, which cover historical aspects related to development of anticancer immunocytokines [1-6].

Some of the most popular immunocytokine formats for IL2, IL12 and TNF are shown in Figure 1. Cytokine moieties can be genetically fused to various sites on IgG molecules (e.g., at the N- or at the C-terminus). If the immunoglobulin moiety of an immunocytokine has not been intentionaly altered (normally through specific mutations at judiciously chosen sites), it should retain its functional properties, such as binding to Fc gamma receptors, to the complement cascadeinitiating factor $\mathrm{C1q}$, the $\mathrm{pH}$-dependent interaction with the neonatal $\mathrm{FcRn}$ receptor, as well as antigen binding activity. In addition, the cytokine component of the immunocytokine should also preserve an intact cytokine activity. Interestingly, the positioning of the cytokine moiety and the use of suitable linkers may facilitate the development of products, with adaptable immunostimulatory activity upon antigen binding [7]. 
Immunocytokines based on antibody fragments have a simpler functional activity, as they only consist of two moieties (i.e., the cytokine and the antigen binding portion of the antibody). In contrast to full IgG-based immunocytokines ( 180 kDa), these smaller products (45-130 kDa) are rapidly cleared from circulation. However, favorable tumor:organ ratios have been reported for fragment-based immunocytokine products in various quantitative biodistribution studies performed in mouse models of cancer [e.g., 4, 8-10 and references therein]. Interestingly, certain payloads (e.g., IL2, IL4, IL6, IL9, IL10, IL12, interferon-alpha, TNF] can be efficiently delivered to the tumor by suitable antibodies, while other payloads (e.g., those with heavy glycosylation or with extreme isoelectric points) have been shown to abrogate the tumor targeting potential of the parental antibody [9-13]. Interestingly, payloads with abundant receptors distributed in vivo (e.g., interferon-gamma) can be adsorbed by these receptors when infused in vivo at low doses, thereby inhibiting targeting of the immunocytokine to the tumor. However, adequate tumor-targeting performance is recovered with higher dosing, once the cognate receptors have been saturated [14] or when interferon-gamma receptor knock-out mice are used [15].

\section{Mechanism of action}

Immunocytokine products, which are specific to tumor-associated antigens on the cell membrane, have the potential to bridge tumor cells and certain leukocytes (e.g., T cells, or NK cells), in analogy to what could be achieved by using bispecific antibodies [16-19; Figure 2]. By contrast, immunocytokines which target tumor-associated extracellular matrix components (e.g., splice isoforms of fibronectin or of tenascin-C) [4], are believed to mainly display a biological activity which results from the high-density anchoring of the cytokine moiety at the site of disease. Analysis of tumor infiltrate following pro-inflammatory immunocytokine treatment in mouse models of cancer and in patients has clearly revealed an increased density of leukocytes (including T cells and NK cells) in the neoplastic mass [20-24]. When created using an antibody that targets an antigen on the tumor cell membrane, bispecific antibodies and immunocytokine products could be considered as functionally similar tools for the selective activation of leukocytes at the tumor site. The type of leukocytes activated would be determined by the other antibody component of the bispecific antibody or the cytokine payload of the immunocytokine. For example both can potentially redirect the killing of tumor cells by cytotoxic T lymphocytes without MHC restriction. However, antigen loss by tumor cells may represent an escape strategy for the neoplasm from mAbs that recognize the surface antigen, and thus from bispecific antibodies or immunocytokines that use them. By contrast, immunocytokines that are created 
with antibodies that recognize tumor-related antigens that are not on the tumor cells themselves (such as extracellular matrix molecules or released necrotic nuclear components) are less affected by loss of antigen expression by individual tumor cells and can still simultaneously activate various types of leukocytes (e.g., T cells and NK cells).

Immunocytokines can activate various components of the immune system against neoplastic cells. The specific characteristics largely depend on the cytokine moiety. For example, IL2-based immunocytokines can potently activate both $\mathrm{T}$ cells and NK cells. It is widely assumed that CD8 ${ }^{+}$ $\mathrm{T}$ cells, directed against tumor-associated antigens or mutated peptides, may be present in cancer patients, sometimes with reduced activity due to a variety of suppressive mechanisms (e.g., action of regulatory $\mathrm{T}$ cells within the neoplastic mass). In addition, NK cells may recognize stress antigens (e.g., MIC-A) or other NK activating moieties on the surface of cancer cells, triggering the release of cytotoxic granuli. Changes in cytokine concentration at the tumor site may help boost these pre-existing components of the immune response against neoplasms. Interestingly, some cytokine payloads (e.g., TNF) have the ability to convert tumor masses into black scabs, which may eventually disappear without leaving a scar, revealing (both macroscopically and microscopically) a biological activity on the tumor neo-vasculature [25]. By contrast, other cytokine moieties may reduce tumor size without apparent macroscopic changes to the appearance of neoplastic lesions.

\section{$\underline{\text { Combination strategies and clinical development programs }}$}

Many types of combination regimens have been evaluated for anti-tumor immunocytokines at the preclinical level. Combination partners included drugs [e.g., 25-27], intact antibodies [e.g., 28], radiation [e.g., 29,30] and other immunocytokine products [e.g., 23, 31-34]. The incorporation of two immunocytokine moieties into the same product has been proposed [35], but, depending upon configuration, may result in the abrogation of the tumor targeting properties of the parental immunocytokine products [31].

Table 1 reports a list of immunocytokine products, which have entered clinical trials (alone or in combination with other agents) for the treatment of patients with various types of malignancies. The products feature IL2, IL12 or TNF as pro-inflammatory moieties. Some (e.g., Hu14.18-IL2, NHS-IL2LT, anti-CEA-IL2v, BC1-IL12, DI-Leu16-IL2) are based on intact IgG formats, some (e.g., L19-IL2, F16-IL2, L19-TNF) on antibody fragments. 
Preclinical data with non-mutated IL2 linked to intact IgG molecules have demonstrated far more potent antitumor efficacy in tumor-bearing mice than comparable amounts of the antibody and IL2 given simultaneously as separate molecules [36], even though these immunocytokines have a substantially shorter in vivo half-life (after intravenous injection) than the intact mAb. For example, DI-Leu16-IL2 (an anti-CD20 immunocytokine) was far more effective against human CD20+ lymphoma cells in immunodeficient mice than 25 fold greater doses of anti-CD20 mAb plus IL2 [37]. In the initial trial of DI-leu16-IL2, for B-cell lymphoma patients that relapsed following prior anti-CD20 therapy, 5 of 13 evaluable patients showed CR ( 3 patients) or PR (2 patients) [38]. Preclinical data with the hu14.18-IL2 (anti-GD2) immunocytokine showed that effects were most apparent against microscopic, rather than large tumors [39]. When tested in a phase-II study for children with relapsed/refractory neuroblastoma, no responses were seen in 13 children with bulky (radiologically evident) disease, but 5 children out of 23 with evaluable (but not bulky) disease (detected only by sensitive ${ }^{123}$ I-MIBG nuclear scintigraphy, or by identification of tumor cells in bone marrow aspirates) showed CR [40], consistent with the preclinical data [39].

Two IL2-based immunocytokines (L19-IL2 and F16-IL2), featuring antibody fragments in noncovalent diabody formats, have been tested in Phase I and Phase II clinical trials. The L19 antibody is specific to the alternatively-spliced EDB domain of fibronectin, a marker of tumor angiogenesis, while F16 recognizes the A1 domain of tenascin-C. L19-IL2 has been used as monotherapeutic agent for the treatment of metastatic renal cell carcinoma [41] and in combination with dacarbazine for the treatment of metastatic melanoma [42]. The product is currently being studied in combination with rituximab for the last-line treatment of patients with diffuse large B-cell lymphoma [28]. F16-IL2 has been used in combination with doxorubicin or paclitaxel for the treatment of various types of malignancies [43], or in combination with lowdose cytarabine for the treatment of acute myeloid leukemia [27; 44].

L19-TNF is a non-covalent homotrimeric immunocytokine, resulting from the fusion of human TNF with the L19 antibody in scFv format. The product has been administered systemically to patients with various types of malignancies [45], as well as in isolated limb perfusion procedures to patients with in-transit melanoma metastases [46]. Following the observation of cancer cures and the induction of protective immunity in immunocompetent mouse models of soft-tissue 
sarcoma (STS), L19-TNF is currently being investigated in combination with doxorubicin for the treatment of STS.

Interestingly, the IL2 and TNF moieties have been found to potently synergize, when the corresponding immunocytokines were administered systemically [47] or intralesionally [34] to tumor-bearing mice. L19-IL2 has been given intralesionally to patients with Stage III melanoma, with encouraging results [48]. The therapeutic activity was potentiated by the combination with L19-TNF [49] and a neo-adjuvant Phase III clinical trial has recently started.

Preclinically, the intratumoral injection of the hu14.18-IL2 anti-GD2 immunocytokine (versus intravenous administration), induces greater NK and $\mathrm{T}$ cell infiltration into tumors, has a more potent anti-tumor effect and depends on the activity of both NK and T cells [50]. When combined with local measures of tumor destruction [either radiofrequency ablation (RFA) or external beam radiation therapy] to the same tumor receiving intratumoral immunocytokine, the local action against the treated tumor is more potent; a tumor-specific $\mathrm{T}$ cell response is induced that shows epitope spread to antigens other than GD2 on the tumor and antitumor activity is seen against distant disease [51,52]. In this setting the intratumoral immunocytokine combined with the RFA or radiotherapy is enabling the injected tumor to function as an effective in situ vaccine (treating locally in order to act systemically).

\section{$\underline{\text { Outlook }}$}

While immunocytokine products are advancing in clinical trials, future research activities will be needed in order to more precisely characterize their mechanism of action. Progress in HLApeptidome analysis [53] and in the generation of multiplex tetramer reagents [54] has made it possible, for the first time, to characterize the binding specificity of individual T-cells before and after immunotherapy. These investigations should provide a better understanding of the nature and role of tumor rejection antigens, as well as information on the dynamics and breadth of $\mathrm{T}$ cell specificities in response to therapy [55]. In contrast to the study of T cells, for which analytical tools are available, the mechanistic investigation of NK cells is more difficult. However, since this cell type potently contributes to therapeutic action of immunocytokines, as demonstrated by depletion experiments in preclinical models and by Killer Immunoglobulin-like Receptor (KIR) genotype analyses of clinical data [56], a more detailed understanding of the key molecular events responsible for the anti-tumoral activity of activated NK cells would be desirable. 


\section{Conclusions}

In summary, immunocytokines represent a promising class of activators of the immune system, with the potential to be used alone or in combination with other therapeutic modalities. Proinflammatory immunocytokines are not myelotoxic and can be potentially combined with a number of therapeutic modalities, including other immunotherapies as well as more conventional treatments. More research is needed, in order to identify which cytokine payloads should be preferred for individual cancer indications and which pharmaceutical agents would benefit most from immunocytokine combinations. Finally, while this article focuses exclusively on oncology applications, it should be mentioned that certain immunocytokine products have shown promising therapeutic activity for the treatment of chronic inflammatory conditions [e.g., 57-60] and of endometriosis $[61,62]$ in immunocompetent preclinical models. 


\section{Acknowledgements}

D.N. gratefully acknowledges funding from ETH Zürich, the Swiss National Science Foundation, the Bovena Foundation, the Maiores Foundation, as well as from an ERC Advanced Grant "Zauberkugel".

P.M.S. gratefully acknowledges funding fromThe National Institutes of Health (USA) Grants CA032685, CA87025, CA166105, CA14520, CA197078, GM067386, and grants from the Midwest Athletes for Childhood Cancer Fund, The Crawdaddy Foundation, The Evan Dunbar Foundation, Hyundai Hope on Wheels Foundation, The University of Wisconsin-Madison

Institute for Clinical and Translational Research Grant 1TL1RR025013-01 and Stand Up To Cancer - St. Baldrick's Pediatric Dream Team Translational Research Grant (SU2C-AACRDT1113). 


\section{Figure Captions}

Figure 1: Schematic representation of various antibody formats, used for the production of immunocytokines based on IL2, IL12 or TNF. (a and b): IgG- based immunocytokines with the IL2 moiety at the C-terminal end of heavy and light chain, respectively; (c) diabody-IL2 fusion protein format; (d) homotrimeric scFv-TNF fusion proteins; (e) heterodimeric immunocytokines, in which a scFv moiety is fused to both p40 and 35 subunits of IL12.

Figure 2: Schematic representation of a comparative analysis, between the simultaneous engagement of tumor cells and T cells (or NK cells) by bispecific antibodies and by IL2-based immunocytokines. 


\section{Table 1: List of anticancer immunocytokine products in clinical trials}

$\begin{array}{lllll}\text { Product Name } & \text { Cytokine } & \text { Target Antigen } & \text { Format } & \text { Reference } \\ \text { Hu14.18-IL2 } & \text { IL2 } & \text { GD2 } & \text { IgG } & 40 \\ \text { NHS-IL2LT } & \text { IL2 } & \text { Nuclear antigen } & \text { IgG } & 29 \\ \text { anti-CEA-IL2v } & \text { IL2 } & \text { CEA } & \text { IgG } & \\ \text { DI-Leu16-IL2 } & \text { IL2 } & \text { CD20 } & \text { IgG } & 38 \\ \text { HuKS-IL2 } & \text { IL2 } & \text { EpCAM } & \text { IgG } & 64 \\ \text { NHS-IL12 } & \text { IL12 } & \text { Nuclear antigen } & \text { IgG } & \\ \text { BC1-IL12 } & \text { IL12 } & \text { Domain 7 of FN } & \text { IgG } & 63 \\ \text { L19-IL2 } & \text { IL2 } & \text { EDB of FN } & \text { diabody } & 41,42,48,49 \\ \text { F16-IL2 } & \text { IL2 } & \text { A1 of Tn-C } & \text { diabody } & 27,43,44 \\ \text { L19-TNF } & \text { TNF } & \text { EDB of FN } & \text { scFv } & 45,46,49\end{array}$

Legend to Table 1: List of antibody-cytokine fusion proteins, which have been investigated in clinical trials in oncology. The cytokine moiety and the target antigen are indicated. Nuclear antigen $=$ histone recognized by the hTNT3 antibody; GD2 = disialoganglioside; CEA $=$ carcinoembryonic antigen. Domain 7 of $\mathrm{FN}=$ epitope on domain 7 of fibronectin, which is cryptic in the presence of the alternatively-spliced EDB domain. EDB of FN = EDB domain of fibronectin. EpCAM = Epithelial Cell Adhesion Molecule. A1 of Tn-C = alternatively-spliced A1 domain of tenascin-C. 


\section{References}

$*=$ of special interest

$* *=$ of outstanding interest

[1] Sondel PM, Gillies SD.

Current and Potential Uses of Immunocytokines as Cancer Immunotherapy.

Antibodies (Basel). 2012 Jul 4;1(2):149-171.

[2] Schrama D, Reisfeld RA, Becker JC.

Antibody targeted drugs as cancer therapeutics.

Nat Rev Drug Discov. 2006 Feb;5(2):147-59.

[3] Young PA, Morrison SL, Timmerman JM.

Antibody-cytokine fusion proteins for treatment of cancer: engineering cytokines for improved efficacy and safety.

Semin Oncol. 2014 Oct;41(5):623-36.

[4] Pasche N, Neri D.

Immunocytokines: a novel class of potent armed antibodies.

Drug Discov Today. 2012 Jun;17(11-12):583-90.

[5] Bootz F, Neri D.

Immunocytokines: a novel class of products for the treatment of chronic inflammation and autoimmune conditions.

Drug Discov Today. 2016 Jan;21(1):180-9.

[6] Müller D.

Antibody fusions with immunomodulatory proteins for cancer therapy.

Pharmacol Ther. 2015 Oct;154:57-66.

**[7] Gillies SD.

A new platform for constructing antibody-cytokine fusion proteins (immunocytokines) with improved biological properties and adaptable cytokine activity.

Protein Eng Des Sel. 2013 Oct;26(10):561-9.

The original immunocytokine configuration involved placement of IL2 on the carboxy termini if each IgG heavy chain. This permitted the IL2 component to bind to high and intermediate affinity IL2 receptors comparably to soluble IL2. In order to modify function and activity many other configurations have been developed. Here, Steve Gillies demonstrates that moving the IL2 to the carboxy termini of the IgG light chains allows the IL2 component to retain full interactions with the high affinity IL2 receptor, but decreases its interaction with the intermediate affinity IL2 receptor. This may have advantages in vivo, for retaining anti-tumor activity with less IL2induced dose-dependent toxicity.

[8] Hemmerle T, Hess C, Venetz D, Neri D.

Tumor targeting properties of antibody fusion proteins based on different members of the murine tumor necrosis superfamily.

J Biotechnol. 2014 Feb 20;172:73-6. 
*[9] Venetz D, Hess C, Lin CW, Aebi M, Neri D.

Glycosylation profiles determine extravasation and disease-targeting properties of armed antibodies.

Proc Natl Acad Sci U S A. 2015 Feb 17;112(7):2000-5.

The article revealed how certain glycoforms may negatively impact on the pharmacokinetics and disease-targeting properties of antibody-cytokine fusion proteins

[10] Hemmerle T, Wulhfard S, Neri D.

A critical evaluation of the tumor-targeting properties of bispecific antibodies based on quantitative biodistribution data.

Protein Eng Des Sel. 2012 Dec;25(12):851-4.

[11] Melkko S, Halin C, Borsi L, Zardi L, Neri D.

An antibody-calmodulin fusion protein reveals a functional dependence between macromolecular isoelectric point and tumor targeting performance.

Int J Radiat Oncol Biol Phys. 2002 Dec 1;54(5):1485-90.

[12] Niesner U, Halin C, Lozzi L, Günthert M, Neri P, Wunderli-Allenspach H, Zardi L, Neri D. Quantitation of the tumor-targeting properties of antibody fragments conjugated to cellpermeating HIV-1 TAT peptides.

Bioconjug Chem. 2002 Jul-Aug;13(4):729-36.

[13] Halin C, Niesner U, Villani ME, Zardi L, Neri D.

Tumor-targeting properties of antibody-vascular endothelial growth factor fusion proteins.

Int J Cancer. 2002 Nov 10;102(2):109-16.

[14] Hemmerle T, Neri D.

The dose-dependent tumor targeting of antibody-IFN $\gamma$ fusion proteins reveals an unexpected receptor-trapping mechanism in vivo.

Cancer Immunol Res. 2014 Jun;2(6):559-67.

[15] Ebbinghaus C, Ronca R, Kaspar M, Grabulovski D, Berndt A, Kosmehl H, Zardi L, Neri D. Engineered vascular-targeting antibody-interferon-gamma fusion protein for cancer therapy.

Int J Cancer. 2005 Aug 20;116(2):304-13.

[16] Frankel SR, Baeuerle PA.

Targeting T cells to tumor cells using bispecific antibodies.

Curr Opin Chem Biol. 2013 Jun;17(3):385-92.

[17] Reusch U, Duell J, Ellwanger K, Herbrecht C, Knackmuss SH, Fucek I, Eser M, McAleese F, Molkenthin V, Gall FL, Topp M, Little M, Zhukovsky EA.

A tetravalent bispecific TandAb (CD19/CD3), AFM11, efficiently recruits T cells for the potent lysis of CD19(+) tumor cells.

MAbs. 2015;7(3):584-604.

[18] Gubbels JAA, Gadbaw B, Buhtoiarov IN, Horibata S, Kapur AK, Patel D, Hank JA, Gillies SD, Sondel PM, Connor J, Patankar MS.

Ab-IL2 Fusion Proteins Mediate NK Cell Immune Synapse Formation by Polarizing CD25 to the Target Cell-Effector Cell Interface. 
Cancer Immunol Immunother. 2011 Dec;60(12):1789-800.

*[19] Buhtoiarov IN, Neal ZC, Gan J, Buhtoiarova TN, Patankar MS, Gubbels JA, Hank JA, Yamane B, Rakhmilevich AL, Reisfeld RA, Gillies SD, Sondel PM.

Differential internalization of hu14.18-IL2 immunocytokine by NK and tumor cell: impact on conjugation, cytotoxicity and targeting.

J. Leukocyte Biol. 2011 Apr;89(4):625-38.

By evaluating NK cell binding and conjugate formation, the authors of this and the prior reference (Gubbels et al) demonstrated additional biological activities for immunocytokines, not seen with naked antibodies, IL2 or the 2 molecules used in combination. In particular, immunocytokines comprised of tumor-reactive mAbs and IL2 could enable NK cells to bind to immunocytokine treated tumor cells using their IL2 receptors, resulting in an activated immune synapse and polarization of the IL2 receptors.

[20] Carnemolla B, Borsi L, Balza E, Castellani P, Meazza R, Berndt A, Ferrini S, Kosmehl H, Neri D, Zardi L.

Enhancement of the antitumor properties of interleukin-2 by its targeted delivery to the tumor blood vessel extracellular matrix.

Blood. 2002 Mar 1;99(5):1659-65.

[21] Lode HN, Xiang R, Gillies SD, Reisfeld RA.

Amplification of T cell-mediated immune responses by antibody-cytokine fusion proteins.

Immunol Invest. 2000 May;29(2):117-20.

[22] Halin C, Rondini S, Nilsson F, Berndt A, Kosmehl H, Zardi L, Neri D.

Enhancement of the antitumor activity of interleukin-12 by targeted delivery to neovasculature.

Nat Biotechnol. 2002 Mar;20(3):264-9.

[23] Hemmerle T, Neri D.

The antibody-based targeted delivery of interleukin- 4 and 12 to the tumor neovasculature eradicates tumors in three mouse models of cancer.

Int J Cancer. 2014 Jan 15;134(2):467-77.

*[24] Helguera G, Dela Cruz JS, Lowe C, Ng PP, Trinh R, Morrison SL, Penichet ML. Vaccination with novel combinations of anti-HER2/neu cytokines fusion proteins and soluble protein antigen elicits a protective immune response against HER2/neu expressing tumors. Vaccine. 2006 Jan 16;24(3):304-16.

The article reveals an intriguing mechanism of action for certain immunocytokines, based on IL2, IL12 or GMCSF as payload. These fusion proteins may form complexes with the cognate soluble antigen and stimulate a potent anticancer response.

*[25] Hemmerle T, Probst P, Giovannoni L, Green AJ, Meyer T, Neri D.

The antibody-based targeted delivery of TNF in combination with doxorubicin eradicates sarcomas in mice and confers protective immunity.

Br J Cancer. 2013 Sep 3;109(5):1206-13.

Two immunocompetent syngeneic mouse models of soft tissue sarcoma could be cured by the combined action of a TNF-based immunocytokine and doxorubicin. Cured mice acquired a protective immunity, against subsequent challenges with sarcoma tumor cells. 
[26] Mårlind J, Kaspar M, Trachsel E, Sommavilla R, Hindle S, Bacci C, Giovannoni L, Neri D. Antibody-mediated delivery of interleukin- 2 to the stroma of breast cancer strongly enhances the potency of chemotherapy.

Clin Cancer Res. 2008 Oct 15;14(20):6515-24.

[27] Gutbrodt KL, Schliemann C, Giovannoni L, Frey K, Pabst T, Klapper W, Berdel WE, Neri D.

Antibody-based delivery of interleukin-2 to neovasculature has potent activity against acute myeloid leukemia.

Sci Transl Med. 2013 Sep 4;5(201):201ra118.

*[28] Schliemann C, Palumbo A, Zuberbühler K, Villa A, Kaspar M, Trachsel E, Klapper W, Menssen HD, Neri D.

Complete eradication of human B-cell lymphoma xenografts using rituximab in combination with the immunocytokine L19-IL2.

Blood. 2009 Mar 5;113(10):2275-83.

The combined use of the L19-IL2 fusion protein with Rituximab could eradicate lymphomas grafted in immunocompromised mice (which still had NK cells). The same models could not be cured by Rituximab alone or by the combination of Rituximab and "untargeted" IL2. The L19IL2 product promoted an influx of NK cells at the site of disease, boosting ADCC activity.

[29] van den Heuvel MM, Verheij M, Boshuizen R, Belderbos J, Dingemans AM, De Ruysscher D, Laurent J, Tighe R, Haanen J, Quaratino S.

NHS-IL2 combined with radiotherapy: preclinical rationale and phase Ib trial results in metastatic non-small cell lung cancer following first-line chemotherapy.

J Transl Med. 2015 Jan 27;13:32.

**[30] Zegers CM, Rekers NH, Quaden DH, Lieuwes NG, Yaromina A, Germeraad WT, Wieten L, Biessen EA, Boon L, Neri D, Troost EG, Dubois LJ, Lambin P.

Radiotherapy combined with the immunocytokine L19-IL2 provides long-lasting antitumor effects.

Clin Cancer Res. 2015 Mar 1;21(5):1151-60.

The combined use of external beam radiation and an IL2-based immunocytokine (L19-IL2) led to cancer cures in mouse models of the disease.

[31] Halin C, Gafner V, Villani ME, Borsi L, Berndt A, Kosmehl H, Zardi L, Neri D.

Synergistic therapeutic effects of a tumor targeting antibody fragment, fused to interleukin 12 and to tumor necrosis factor alpha.

Cancer Res. 2003 Jun 15;63(12):3202-10.

[32] Pasche N, Wulhfard S, Pretto F, Carugati E, Neri D.

The antibody-based delivery of interleukin-12 to the tumor neovasculature eradicates murine models of cancer in combination with paclitaxel.

Clin Cancer Res. 2012 Aug 1;18(15):4092-103.

[33] Hess C, Neri D.

The antibody-mediated targeted delivery of interleukin-13 to syngeneic murine tumors mediates a potent anticancer activity.

Cancer Immunol Immunother. 2015 May;64(5):635-44. 
[34] Schwager K, Hemmerle T, Aebischer D, Neri D.

The immunocytokine L19-IL2 eradicates cancer when used in combination with CTLA-4 blockade or with L19-TNF.

J Invest Dermatol. 2013 Mar;133(3):751-8.

[35] Gillies SD, Lan Y, Brunkhorst B, Wong WK, Li Y, Lo KM.

Bi-functional cytokine fusion proteins for gene therapy and antibody-targeted treatment of cancer. Cancer Immunol Immunother. 2002 Oct;51(8):449-60.

[36] Lode HN, Xiang R, Dreier T, Varki NM, Gillies SD, Reisfeld RA.

Natural killer cell-mediated eradication of neuroblastoma metastases to bone marrow by targeted interleukin-2 therapy.

Blood. 1998. 91(5), 1706-1715.

[37] Gillies SD, Lan Y, Williams S, Carr F, Forman S, Raubitschek A, Lo K-M.

An anti-CD20-IL2 immunocytokine is highly efficacious in a SCID mouse model of established human B lymphoma.

Blood. 2005. 105:3972-3978.

[38] Bachanova V, Lansigan F, Quick D, Vlock D, GIllies S, Nakamura R.

Remission Induction in a phaseI/II study of an anti-CD20-Interleukin-2 immunocytokine DILeu16-IL2 in patients with relapsed B-cell lymphoma.

Blood. 2016, (Abstract \#1533, ASH, 2015).

[39] Neal ZC, Yang JC, Rakhmilevich AL, Buhtoiarov I, Lum HE, Imboden M, Hank JA, Lode HN, Reisfeld RA, Gillies SD, Sondel PM.

Enhanced activity of hu14.18-IL2 IC against the murine NXS2 neuroblastoma when combined with IL2 therapy.

Clin Cancer Res. 2004 Jul 15;10(14):4839-47.

**[40] Shusterman S, London WB, Gillies SD, et al. Hank JA, Voss S, Seeger RC, Reynolds CP, Kimball J, Albertini MA, Wagner B, Gan J, Eickhoff J, DeSantes KD, Cohn SL, Hecht T, Gadbaw B, Reisfeld RA, Maris JM, Sondel PM.

Anti-tumor activity of hu14.18-IL2 in patients with relapsed/refractory neuroblastoma: a Children's Oncology Group (COG) Phase II study.

J. Clin Oncol. 2010 Nov 20;28(33):4969-75.

This Children's Oncology Group phase-II trial tested the activity of the hu14.18-IL2 immunocytokine for children with relapsed/refractory neuroblastoma. In the group of children with bulky disease, anti-tumor activity was not seen. In the group of children with disease evaluated by nuclear scintigraphy with ${ }^{123}$ I-MIBG or by bone marrow histology detection of tumor cells, 5 of 24 patients showed complete responses. These data were consistent with prior preclinical results, indicating that immunocytokines are more effective for solid tumors when used in non-bulky disease conditions.

[41] Johannsen M, Spitaleri G, Curigliano G, Roigas J, Weikert S, Kempkensteffen C, Roemer A, Kloeters C, Rogalla P, Pecher G, Miller K, Berndt A, Kosmehl H, Trachsel E, Kaspar M, Lovato V, González-Iglesias R, Giovannoni L, Menssen HD, Neri D, de Braud F.

The tumour-targeting human L19-IL2 immunocytokine: preclinical safety studies, phase I clinical 
trial in patients with solid tumours and expansion into patients with advanced renal cell carcinoma.

Eur J Cancer. 2010 Nov;46(16):2926-35.

[42] Eigentler TK, Weide B, de Braud F, Spitaleri G, Romanini A, Pflugfelder A, GonzálezIglesias R, Tasciotti A, Giovannoni L, Schwager K, Lovato V, Kaspar M, Trachsel E, Menssen HD, Neri D, Garbe C.

A dose-escalation and signal-generating study of the immunocytokine L19-IL2 in combination with dacarbazine for the therapy of patients with metastatic melanoma.

Clin Cancer Res. 2011 Dec 15;17(24):7732-42.

[43] Catania C, Maur M, Berardi R, Rocca A, Giacomo AM, Spitaleri G, Masini C, Pierantoni C, González-Iglesias R, Zigon G, Tasciotti A, Giovannoni L, Lovato V, Elia G, Menssen HD, Neri D, Cascinu S, Conte PF, Braud Fd.

The tumor-targeting immunocytokine F16-IL2 in combination with doxorubicin: dose escalation in patients with advanced solid tumors and expansion into patients with metastatic breast cancer. Cell Adh Migr. 2015;9(1-2):14-21.

[44] Schliemann C, Gutbrodt KL, Kerkhoff A, Pohlen M, Wiebe S, Silling G, Angenendt L, Kessler T, Mesters RM, Giovannoni L, Schäfers M, Altvater B, Rossig C, Grünewald I, Wardelmann E, Köhler G, Neri D, Stelljes M, Berdel WE.

Targeting interleukin-2 to the bone marrow stroma for therapy of acute myeloid leukemia relapsing after allogeneic hematopoietic stem cell transplantation.

Cancer Immunol Res. 2015 May;3(5):547-56.

[45] Spitaleri G, Berardi R, Pierantoni C, De Pas T, Noberasco C, Libbra C, González-Iglesias R, Giovannoni L, Tasciotti A, Neri D, Menssen HD, de Braud F.

Phase I/II study of the tumour-targeting human monoclonal antibody-cytokine fusion protein L19-TNF in patients with advanced solid tumours.

J Cancer Res Clin Oncol. 2013 Mar;139(3):447-55.

[46] Papadia F, Basso V, Patuzzo R, Maurichi A, Di Florio A, Zardi L, Ventura E, GonzálezIglesias R, Lovato V, Giovannoni L, Tasciotti A, Neri D, Santinami M, Menssen HD, De Cian F. Isolated limb perfusion with the tumor-targeting human monoclonal antibody-cytokine fusion protein L19-TNF plus melphalan and mild hyperthermia in patients with locally advanced extremity melanoma.

J Surg Oncol. 2013 Feb;107(2):173-9.

[47] Balza E, Carnemolla B, Mortara L, Castellani P, Soncini D, Accolla RS, Borsi L. Therapy-induced antitumor vaccination in neuroblastomas by the combined targeting of IL-2 and TNFalpha.

Int J Cancer. $2010 \mathrm{Jul}$ 1;127(1):101-10.

[48] Weide B, Eigentler TK, Pflugfelder A, Zelba H, Martens A, Pawelec G, Giovannoni L, Ruffini PA, Elia G, Neri D, Gutzmer R, Becker JC, Garbe C.

Intralesional treatment of stage III metastatic melanoma patients with L19-IL2 results in sustained clinical and systemic immunologic responses.

Cancer Immunol Res. 2014 Jul;2(7):668-78. 
*[49] Danielli R, Patuzzo R, Di Giacomo AM, Gallino G, Maurichi A, Di Florio A, Cutaia O, Lazzeri A, Fazio C, Miracco C, Giovannoni L, Elia G, Neri D, Maio M, Santinami M.

Intralesional administration of L19-IL2/L19-TNF in stage III or stage IVM1a melanoma patients: results of a Phase II study.

Cancer Immunol Immunother. 2015 Aug;64(8):999-1009.

In this Phase II clinical trial, the intralesional administration of the combination of two immunocytokines (L19-IL2 and L19-TNF) led to the disappearance of most injected lesions in patients with metastatic skin lesions of melanoma. Importantly, as effect on non-injected lesions was also observed.

[50] Yang RK, Kalogriopoulos NA, Rakhmilevich AL, Ranheim EA, Seo S, Kim KM, Alderson KL, Gan J, Reisfeld RA, Gillies SD, Hank JA, Sondel PM.

Intratumoral hu14.18-IL2 (IC) Induces Local and Systemic Antitumor Effects that Involve Both Activated T- and NK cells as well as Enhanced IC Retention.

J Immunol. 2012 Sep 1;189(5):2656-64.

[51] Johnson EE, Yamane BH, Lum HD, Buhtoiarov IN, Rakhmilevich AL, Mahvi DM, Gillies SD, Sondel PM.

Radiofrequency Ablation Combined with KS-IL2 IC (EMD 273066) Results in an Enhanced Anti-tumor Effect Against Murine Colon Adenocarcinoma.

Clin Cancer Res. 2009 Aug 1;15(15):4875-84.

[52] Morris ZS, Emily I. Guy EI, Francis DM, Gressett MM, Carmichael LL, Yang RK, Armstrong EA, Huang S, Navid F, Gillies SD, Korman A, Hank JA, Rakhmilevich AL, Harari PM, Sondel PM.

Combining Local Radiation and tumor-specific antibody or IC to elicit in situ tumor vaccination. In re-review, 2016.

[53] Caron E, Kowalewski DJ, Chiek Koh C, Sturm T, Schuster H, Aebersold R. Analysis of Major Histocompatibility Complex (MHC) Immunopeptidomes Using Mass Spectrometry. Mol Cell Proteomics. 2015 Dec;14(12):3105-17.

**[54] Hadrup SR, Bakker AH, Shu CJ, Andersen RS, van Veluw J, Hombrink P, Castermans E, Thor Straten P, Blank C, Haanen JB, Heemskerk MH, Schumacher TN.

Parallel detection of antigen-specific T-cell responses by multidimensional encoding of MHC multimers.

Nat Methods. 2009 Jul;6(7):520-6.

This ladmark paper showed how MHC tetramers can be loaded with multiple peptides, using an ingenious substitution of a photoactivatable peptide. The technology paved the way to the multiplex analysis of $T$ cell specificities in vivo.

[55] Kvistborg P, Philips D, Kelderman S, Hageman L, Ottensmeier C, Joseph-Pietras D, Welters MJ, van der Burg S, Kapiteijn E, Michielin O, Romano E, Linnemann C, Speiser D, Blank C, Haanen JB, Schumacher TN.

Anti-CTLA-4 therapy broadens the melanoma-reactive CD8+ T cell response.

Sci Transl Med. 2014 Sep 17;6(254):254ra128. 
[56] Delgado DC, Hank JA, Kolesar J, Lorentzen D, Gan J, Seo S, Kim KM, Shusterman S, Gillies SD, Reisfeld RA, Yang R, Gadbaw B, DeSantes KD, London WB, Seeger RC, Maris J, and Sondel PM.

Genotypes of NK Cell KIR Receptors, Their Ligands, and Fc $\square$ Receptors in the Response of Neuroblastoma Patients to Hu14.18-IL2 Immunotherapy.

Cancer Res. 2010 Dec 1;70(23):9554-61.

[57] Schwager K, Kaspar M, Bootz F, Marcolongo R, Paresce E, Neri D, Trachsel E.

Preclinical characterization of DEKAVIL (F8-IL10), a novel clinical-stage immunocytokine which inhibits the progression of collagen-induced arthritis.

Arthritis Res Ther. 2009;11(5):R142.

[58] Hemmerle T, Doll F, Neri D.

Antibody-based delivery of IL4 to the neovasculature cures mice with arthritis.

Proc Natl Acad Sci U S A. 2014 Aug 19;111(33):12008-12.

[59] Hemmerle T, Zgraggen S, Matasci M, Halin C, Detmar M, Neri D.

Antibody-mediated delivery of interleukin 4 to the neo-vasculature reduces chronic skin inflammation.

J Dermatol Sci. 2014 Nov;76(2):96-103.

[60] Bootz F, Schmid AS, Neri D.

Alternatively Spliced EDA Domain of Fibronectin Is a Target for Pharmacodelivery Applications in Inflammatory Bowel Disease.

Inflamm Bowel Dis. 2015 Aug;21(8):1908-17.

[61] Schwager K, Bootz F, Imesch P, Kaspar M, Trachsel E, Neri D.

The antibody-mediated targeted delivery of interleukin-10 inhibits endometriosis in a syngeneic mouse model.

Hum Reprod. 2011 Sep;26(9):2344-52.

[62] Quattrone F, Sanchez AM, Pannese M, Hemmerle T, Viganò P, Candiani M, Petraglia F, Neri D, Panina-Bordignon P.

The Targeted Delivery of Interleukin 4 Inhibits Development of Endometriotic Lesions in a Mouse Model.

Reprod Sci. 2015 Sep;22(9):1143-52.

[63] Lo KM, Lan Y, Lauder S, Zhang J, Brunkhorst B, Qin G, Verma R, Courtenay-Luck N, Gillies SD.

huBC1-IL12, an immunocytokine which targets EDB-containing oncofetal fibronectin in tumors and tumor vasculature, shows potent anti-tumor activity in human tumor models.

Cancer Immunol Immunother. 2007 Apr;56(4):447-57.

[64] Connor JP, Cristea MC, Lewis NL, Lewis LD, Komarnitsky PB, Mattiacci MR, Felder M, Stewart S, Harter J, Henslee-Downey J, Kramer D, Neugebauer R and Stupp R.

A phase $1 b$ study of humanized KS-interleukin-2 (huKS-IL2) immunocytokine with cyclophosphamide in patients with EpCAM-positive advanced solid tumors.

BMC Cancer. 2013. Jan; 13:20-32. 


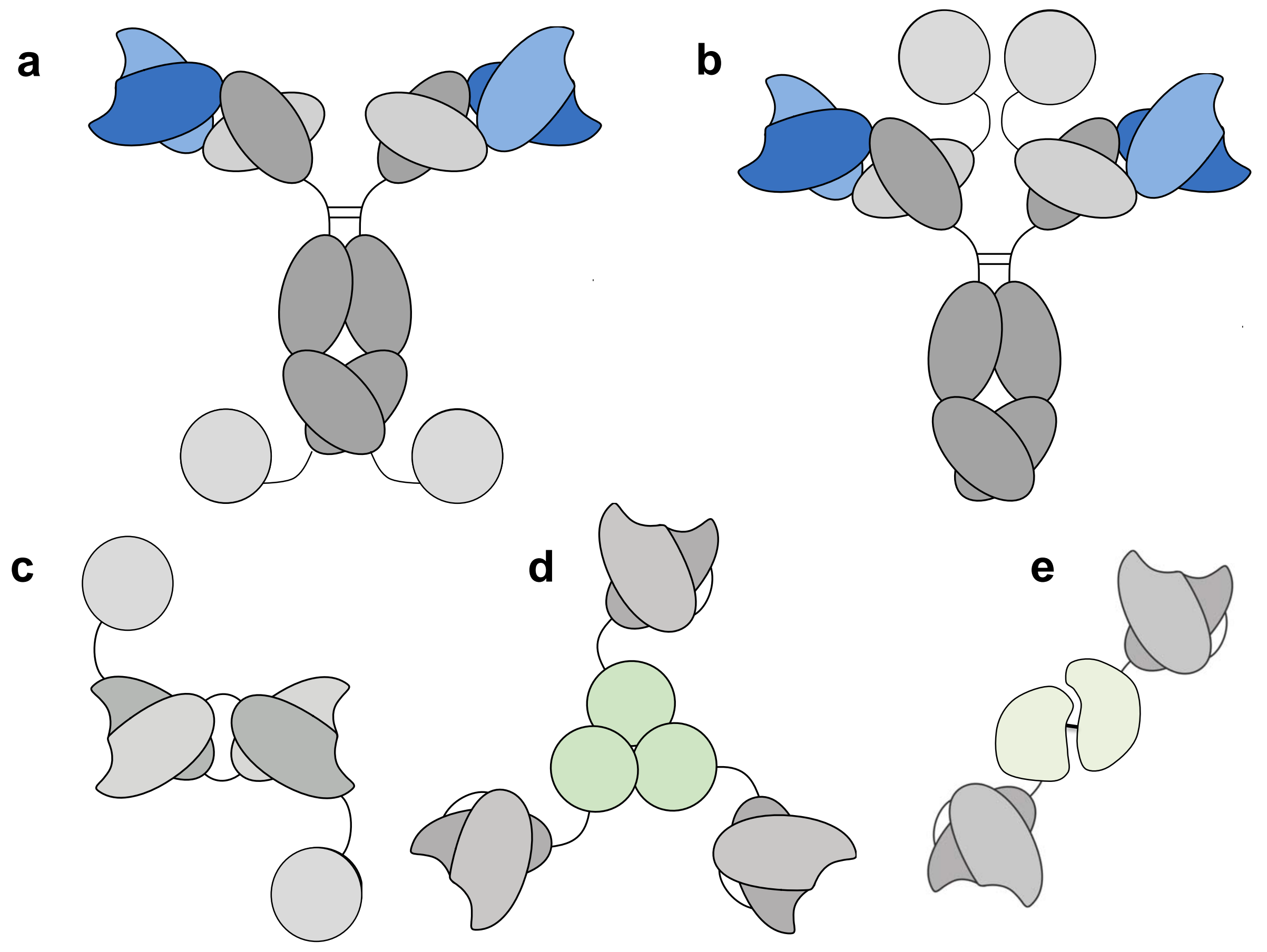




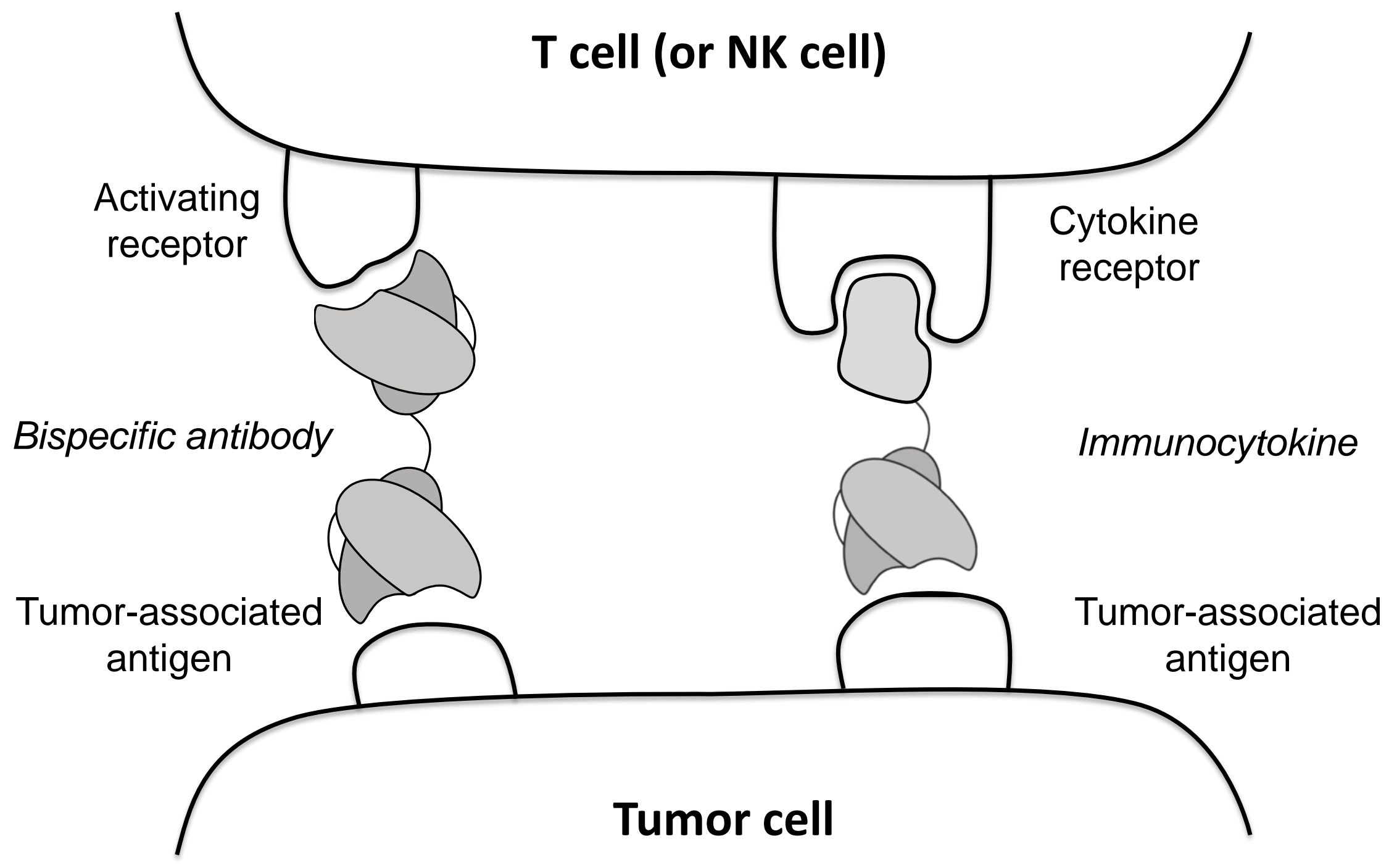

